\title{
UNDERSTANDING THE URBAN POPULATION DENSITY AND GROWTH CONCENTRATION IN PALEMBANG INDONESIA
}

\author{
Muhammad Fajri Romdhoni \\ School of Architecture and Design, University of Kansas \\ Program Studi Arsitektur, Universitas Sriwijaya, Indonesia \\ e-mail: muhammadfajriromdhoni@ku.edu
}

\begin{abstract}
The purpose of this research is to understand the current condition of density, population, and growth concentration in Palembang. As one of the oldest cities in Indonesia, Palembang has been one of the twelve fastest growing cities in Indonesia, with more than one point six million people in 2018. According to the 2018 United Nations World Cities urban report, the Indonesian cities will grow with the annual rate of $2.4 \%$ to $6 \%$, and undoubtedly this growth will impact the city's urban fabric. This paper uses the Landsat images, and OpenStreetMap (OSM) data sets combined with the 2018 Population statistics in Palembang by overlaying the datasets to examine the statistical population growth and urban density in the city Palembang. The research also uses the space syntax method and natural street analysis to determine the human behaviour and traffic movement pattern and how the current urban layout should be examined. This street network's potential will serve as a narrative for further development to the city of Palembang.
\end{abstract}

Keywords: density, population growth, natural street, space syntax, Palembang.

\section{INTRODUCTION}

Urban population density is a piece of essential information to understand a particular city's growth concentration. The methods in analyzing these features have been proven challenging for researchers due to the limitation of the urban and geographical dataset provided for public use. Through internet media, the current Indonesian government has been providing information by using one map feature. However, unfortunately, those maps are still raw and often are not updated for everyday condition analysis purposes. Population density and the growing concentration in a city is significant, and it represents economic activity in an urban environment (Wang, 2006). It is one of the necessary tools for urban designers to assess the development of urban areas. Large-scale analysis of a city has been challenging due to the limited 
data, and traditional data collection has been time-consuming for evaluating urban area densities. This research uses Palembang as a case study to assess the urban population density and concentration of its growth using available tools to help further spatial research on Palembang.

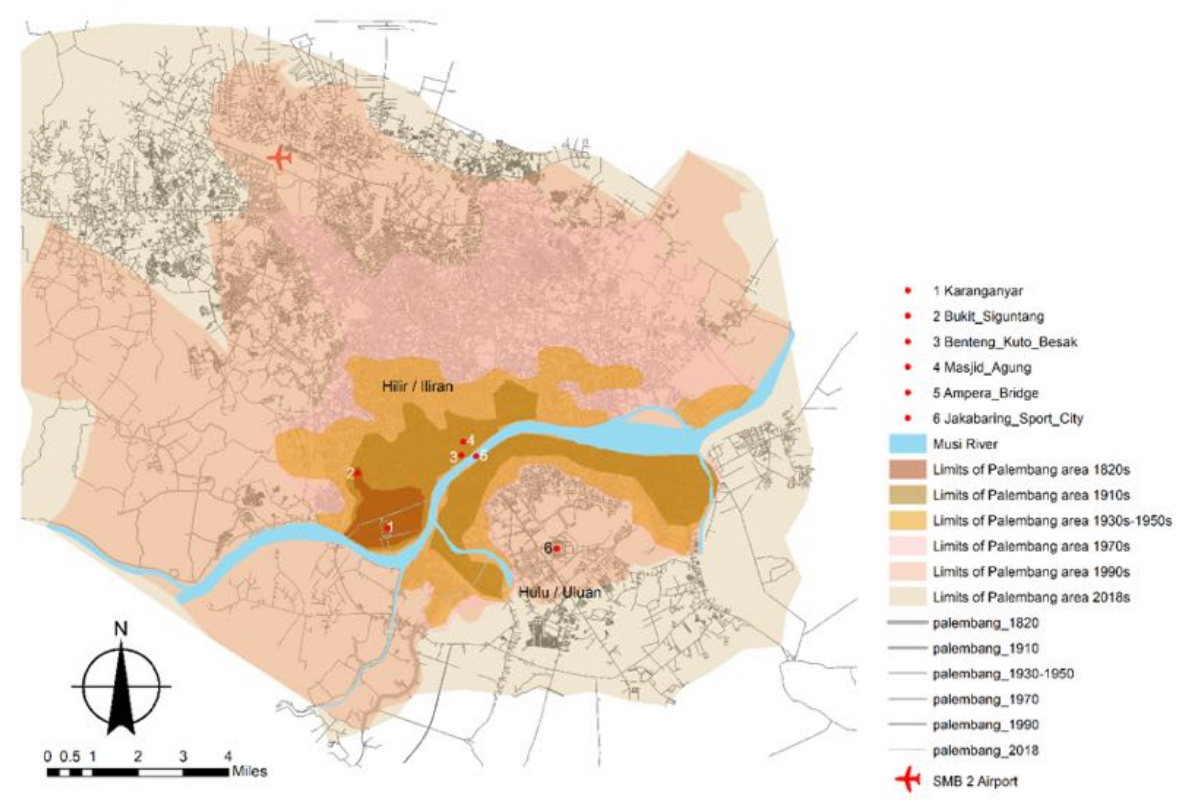

Figure 1. The map shows the main feature and historical morphological phases of Palembang.

Source: Author, 2018

Palembang's city boundaries have been changing over time. The earliest city known boundary for this study was created around the 1820 s, and today Palembang has since used the latest city boundary, with the total administrative size of $338.49 \mathrm{~km} 2$ shown in Figure 1. With the rapid city growth, the city has expanded, merging with the neighbouring administrative area, and the sum size of the city has doubled the size of its administrative area. The lack of information on quantitative population growth represented visually in Palembang has raised a question; if Palembang's administrative area has used the full development of its administrative boundary? From this research, urban growth could be studied further by analyzing the metropolitan built area's growth concentration in Palembang. 

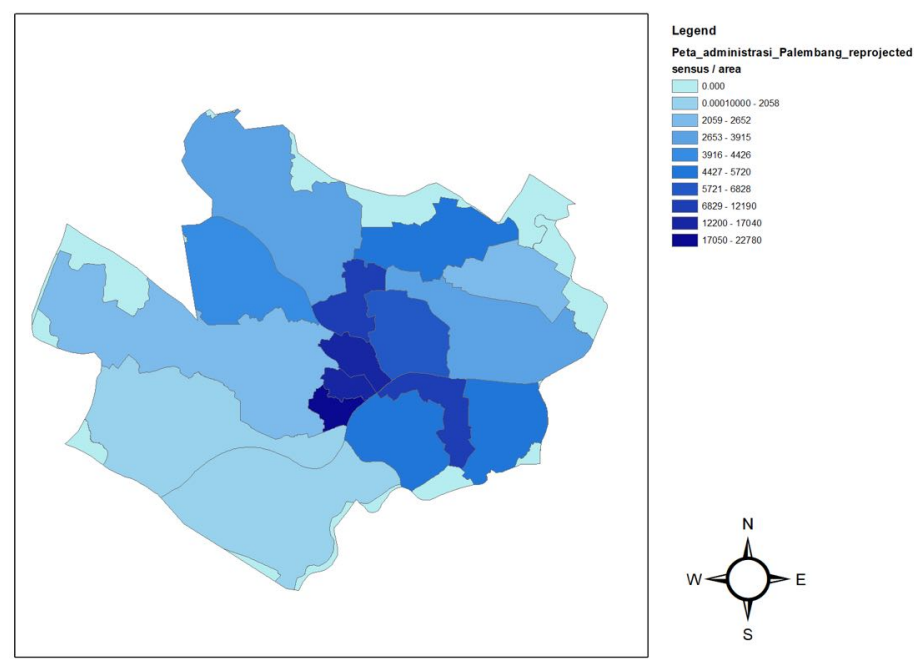

Figure 2. Density map of each administrative area in Palembang.

Source: Author, 2019

This research starts with the availability of census data from Balai Pusat Statistik, providing Palembang's population of its 16 administrative zones. The datasheet is presented in numbers and needs to be visualized in detail. The initial dataset will not assess this case study's real urban density due to the lack of visual representation to describe Palembang's urban density. The course is also using Remote Sensing from Satellite images to determine the LULC / Land Use Land Cover, as well as OpenStreetMap ${ }^{1}$ data that provides the current street centerline to help determine the urban spatial density in the study area.

To understand Palembang's population density condition, the map in Figure 2 shows the 16 administrative areas or kecamatan in the city of Palembang. Those administrative areas are; Plaju, Ilir Timur Satu, Kalidoni, Sukarami, Seberang Ulu Dua, Kemuning, Ilir Timur dua, Alang Alang Lebar, Seberang Ulu Satu, Sematang Borang, Ilir Barat Dua, Ilir Barat Satu, Kertapati, Sako, Bukit Kecil, and Gandus. The collected data is then added to the Table of attributes in ArcMap to create a visual population density of each administrative area. The population density in this figure is the ratio between person per $\mathrm{km} 2$ by dividing the number of census data with the size of the site, and the map of Palembang shows that there are areas that have an overall high density of 22.780 people/ $\mathrm{km} 2$ and the lowest area show a density of 2.000 people/km2.

Although this map shows an overall density in Palembang's administrative area, the plan does not represent Palembang's actual urban density in terms of the number of the built-up area compared to the population ratio. This urban density of built-up area is essential to understand the correlation between population and the actual urban

\footnotetext{
${ }^{1}$ OpenStreetMap, is a Volunteered Geographic Information (VGI), a web-based map that stores geospatial information and generated to support mapping systems available on the internet
} 
land use. Due to the lack of governmental data information, it is difficult for urban studies to understand the actual urban density in a city fully.

\section{THEORY / RESEARCH METHODS}

\section{Urban Density}

Population and urban density have been linked together and creating a bond that affected each other. The urban form is an essential element in the planning process, while the urban density will make a critical formulation to the environment. The drawback of an urban density is the urban sprawl, where planners and urban designers focus on reducing the rigorous impact on an environmental and better understanding of the relationship between urban form, energy, and the environment. Studies in the ecological effects of the urban form and residential density have explained the qualitative value of the policy application in urban planning (Jabareen, 2006; Norman et al., 2006; York University (Jabareen, 2006; Norman et al., 2006; York University (Toronto \& Lang, 1986). However, with current spatial analysis, it is possible to verify the urban density's quantitative value by using Remote sensing images to accurately define the urban density and urban population in a specific area.

The question that is also needed to be answered in this research is the maximum and optimal growth for and administrative boundary? This urban growth could be studied by analyzing the urban density and metropolitan built area of Palembang.

\section{Natural Street}

The knowledge of topographical relationships is needed better to understand the relationship between the underlying street network. There have been many ways to enable urban analysts to see the scaling and living structure through quantitative analysis that could make human activities more predictable and work as a collective human movement behaviour.

The more fundamental method that has been used in this field is the space syntax methods and measures in urban morphological studies. The space syntax has been a substantial body of research since the 1970s and developed by (B. H. Hillier \& Hanson, 1984) that studies the networks of physical spaces on a structural environment and people's systems in society. This body of knowledge has evolved. The space syntax method has been proven using the axial lines-based space syntax to define and predict human activities using the topology of space (B. Hillier, 2007). The natural street as a continuity in the space syntax theory is generated from an individual street segment with the same name and good continuity (Jiang et al., 2008). The natural street is more important in the city scale and somewhat different from the axial line analysis that view the segment analysis in a geometry-based rather than topologyoriented meaning that the natural street is better in predicting the human activities (Jiang et al., 2008; Jiang \& Jia, 2011; Omer \& Jiang, 2015). It is arguable the natural street analysis is showing a better scaling property of the street network and demonstrating that 
1. The natural street is a good representation in predicting human activities.

2. Neither street nor line segment can capture the scaling pattern of human activities. Still, the parameters are converted to the natural road or axial lines graph to have a good sense in social activities correlation.

It is essential to acknowledge that natural street is one of the best representations in terms of human activities and traffic prediction behaviour and ways to conceptualize distances or spaces and the underlying scaling hierarchy of roads and street connectivity (Ma et al., 2019).

\section{Remote Sensing Technique}

The method to define the LULC data is adopting the population census data of 2018. The satellite images are using Landsat images that have been continually monitoring the earth since 1972; this continuation of data is beneficial for validating the longterm evaluation of the model. The satellite image data is obtained from U.S. Geological Survey (USGS) Earth Explorer resources https:/earthexplorer.usgs.gov/ and the specific image chosen for site uses the lowest percentage of cloud cover $(5 \%)$ and high-resolution TIFF images.

The remote sensing process is using the rational linear regression method to distinguish the impervious surface by implementing the Linear Spectral Mixture Analysis / LSMA (Wu \& Murray, 2003) in combination with the ETM+ linear regression method to determine the VIS / Vegetable, impervious material and soil model (Bauer et al., 2007). This process will allow us to predict the Built urban density pixel related to the waterproof surface material.

The regression method is the value of tasselled cap transformations in each band's cost on the remote sensing data. This research and technique have been developed and conducted by Joseph to verify the density value in Port-au-Prince, Haiti(Joseph et al., 2012). Built urban area is done by estimating the continuous imperviousness index using a linear combination of image bands or ratios. In comparison, the dependent variable is the multivariate regression model to estimate the constant imperviousness index from the ETM+ image. The independent variables were derived from the six ETM+ bands with the array of blue, green, red, NIR, SWIR1, and SWIR2 with the three image ratios of NDVI, brightness, and greenness.

Table 1 ETM+ tasselled cap indices measurement

\begin{tabular}{ccccccc}
\hline Index & Band 2 (Blue) & $\begin{array}{c}\text { Band } \\
\text { (Green) }\end{array}$ & $\begin{array}{c}\text { Band } \\
\mathbf{4}(\text { Red) }\end{array}$ & $\begin{array}{c}\text { Round 5 } \\
\text { (NIR) }\end{array}$ & $\begin{array}{c}\text { Round 6 } \\
\text { (SWIR 1) }\end{array}$ & $\begin{array}{c}\text { Band 7 } \\
\text { (SWIR 2) }\end{array}$ \\
\hline $\begin{array}{c}\text { Bright } \\
\text { ness }\end{array}$ & 0.3029 & 0.2786 & 0.4733 & 0.5599 & 0.508 & 0.1872 \\
$\begin{array}{c}\text { Green } \\
\text { ness }\end{array}$ & -0.2941 & -0.243 & -0.5424 & 0.7276 & 0.0713 & -0.1608 \\
$\begin{array}{c}\text { Wet } \\
\text { ness }\end{array}$ & 0.1511 & 0.1973 & 0.3283 & 0.3407 & -0.7117 & -0.4559 \\
\hline
\end{tabular}

The tasselled cap indices in Table is giving a measurement value of Greenness, Brightness and witness of each pixel in the 6 Landsat band (Band2, Band3, Band4, Band5, band6, and Band7). To calculate the Impervious surface using the Tasseled 
Cap index by implementing the statistical model of the multivariate regression (Yang, 2006)

$$
\boldsymbol{I S}=1.285 \boldsymbol{B}-0.189 \boldsymbol{G}-231.757
$$

Where $\boldsymbol{I S}$ is the imperviousness or Impervious surface index and $\mathbf{B}$ and $\mathbf{G}$ is the brightness and greenness derived from the tasselled cap transformation of the ETM+ image or using the Band 2 and Band 3. The adjusted R square value of this model is 0.91 , and the standard error of the estimation is $8.5 \%$. The imperviousness index map is represented in continuous with the diverging sequential colour scheme.

\section{Methodology}

The research is using a methodology based on the datasets analysis and using overlay mapping between different contexts. The first process is to figure out Palembang's population density by having the population from the BPS of Palembang, shown in Figure 3. The second process is to determine the Land Use Land Cover / LULC of Palembang and analyze the city's built-up area. This built-up area is then converted as urban density that defines the population concentration of Palembang.

\begin{tabular}{lrr} 
Peta_administrasi_Palembang \\
\hline \multicolumn{3}{c}{ area } \\
NAMOBJ & 89597 & 43.541917 \\
KERTAPATI & 91619 & 16.584108 \\
SEBERANGULU SATU & 71267 & 3.128133 \\
ILIRBARAT DUA & 88265 & 15.430175 \\
PLAJU & 104209 & 8.551634 \\
SEBERANGULU DUA & 48874 & 2.868432 \\
BUKITKECIL & 64020 & 41.407929 \\
GANDUS & 77102 & 4.994522 \\
ILIRTIMUR SATU & 93352 & 13.672767 \\
ILIRTIMUR DUA & 111030 & 28.362343 \\
KALIDONI & 91419 & 7.915482 \\
KEMUNING & 137863 & 56.343537 \\
ILIRBARAT SATU & 35821 & 13.507808 \\
SEMATANGBORANG & 96886 & 21.891926 \\
ALANG-ALANGLEBAR & 91753 & 17.355365 \\
SAKO & 155590 & 42.922223 \\
SUKARAMI &
\end{tabular}

Figure 3. Census datasheet provided by the source: BPS in Palembang 2018

There has been previous research on the urban form and urban morphology of the city of Palembang and has provided valuable information on the process of growth in the town of Palembang as well as the changes of urban form that has happened (Adiyanto et al., 2018; Nugroho, 2012). The result shows that Palembang's urban 
structure has transformed from a linear city to a radial town and that the current state shows that Palembang is a multinucleated city (Anderson et al., 1996). This research fills the gap to reveal the core of density in Palembang's multinucleated form and shows more embryo of nucleated points in Palembang's urban density.

\section{RESULTS AND DISCUSSIONS}

Using a linear regression method, the population density in this research is used as the dependent variable in the regression model. The population density is the measurement of the number of persons per $\mathrm{km} 2$. There have been several transformations of population density to maximize the model's fitness. The change of datasets shows the built urban area density using dependent population datasets for a particular value of the dependent variable to view the standard deviation to the density value. The density then shows the percentage of the value estimating the thickness of the study area. The model in Figure $\mathbf{2}$ is then modified to visually show the density between the census data model with the built area density model shown in Figure 8. The estimation of this model is taking account of the independent variable of the location, also affect the relative condition of the study area, and giving weight as a neighbouring part of the study area.

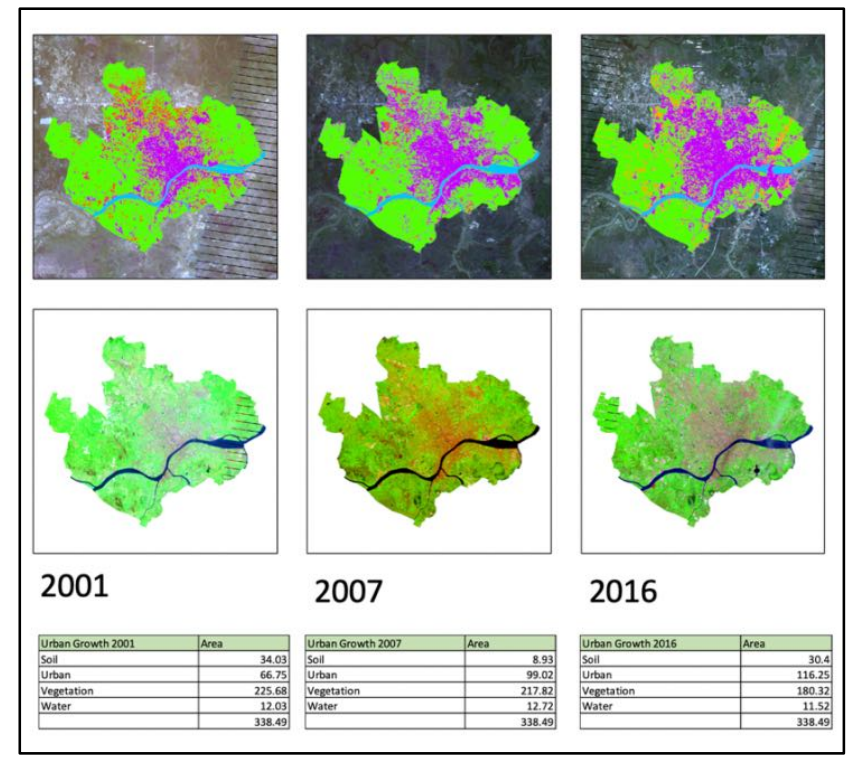

Figure 4. Urban density map transformation in the city of Palembang from 2001 to 2016 Source: Map by Romdhoni, 2019

The initial identification for this research is comparing the Land use and Land Cover / LULC in Palembang into four categories of water, vegetation, urban, and soul defined by the administrative city boundaries. To identify each area, this result uses the tasselled indices value of each land-use provided in previous research of (Joseph et al., 2012). Each index is calculated using the raster calculator and each band from 
the ETM+ Landsat 7 images, and creating new tif image with various low and high value that shows the corrected images for Vegetation, Soil and Urban built area/house.

Based on the identification on the 2018 Landsat Image, we could see the proportion of area in Palembang with the value of the urban area of $26.43 \%$ and the total value of vegetation, soil, and water of $73.57 \%$ from $338.49 \mathrm{~km} 2$ of the administrative region in Palembang.

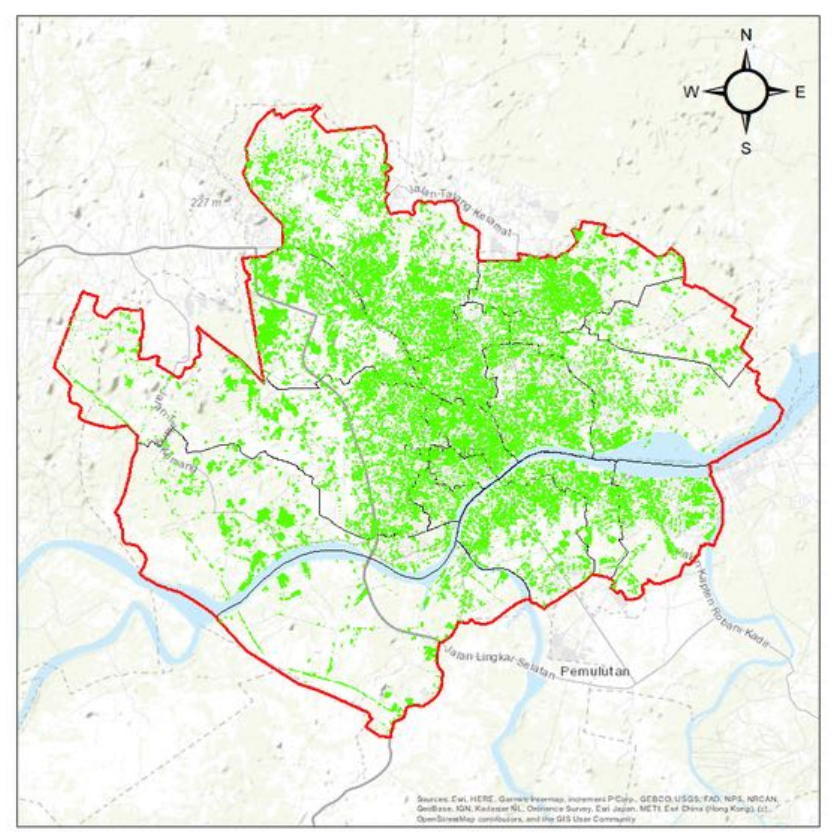

Figure 5. The built urban areas in Palembang in 2018 shown in the green dot colours Source: Author, 2019

The second identification of this research is verifying the growth distribution of the 16 administrative areas in Palembang. The 16 administrative areas in Palembang are respectively Plaju with $15.17 \mathrm{~km} 2$, Seberang Ulu Satu with $10.69 \mathrm{~km} 2$, Seberang Ulu dua with $17.44 \mathrm{~km} 2$, Kertapati with $42.56 \mathrm{~km} 2$, Kalidoni with $27.92 \mathrm{~km} 2$, Ilir Timur dua with $25.58 \mathrm{~km} 2$, Ilir Barat dua with $6.22 \mathrm{~km} 2$, Bukit Kecil with $9.92 \mathrm{~km} 2$, Ilir Timur Satu with $6.5 \mathrm{~km} 2$, Kemuning with 9km2, Sematang Borang with $36.92 \mathrm{~km} 2$, Sako with $18.04 \mathrm{~km} 2$, Sukarami with 51.46km2, Alang Alang Lebar with $34.58 \mathrm{~km} 2$, Ilir Barat Satu with $19.77 \mathrm{~km}$ and Gandus with $68.78 \mathrm{~km} 2$. 

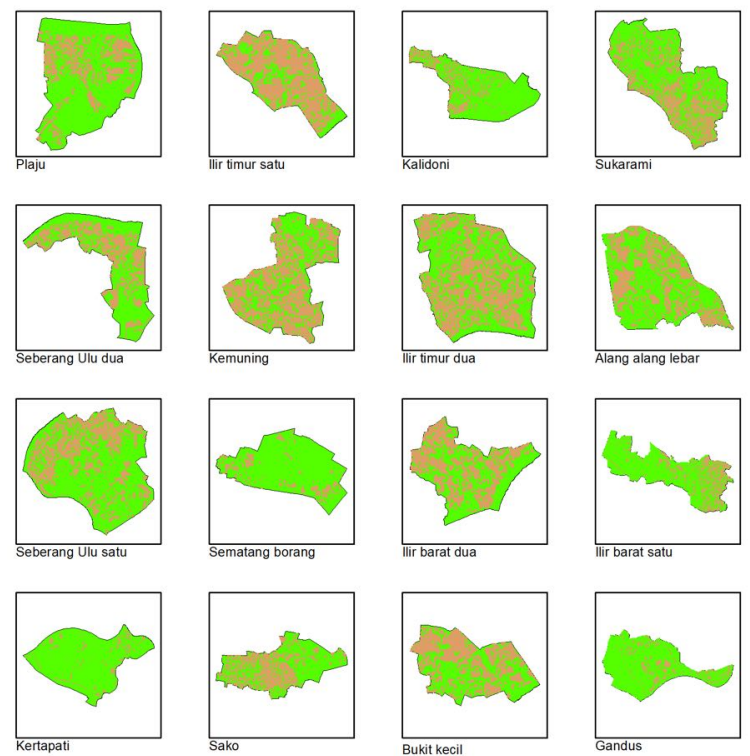

Figure 6. The resulting map of each of the 16 administrative areas in Palembang 2019

Source: Author, 2019

The Administrative area size was divided by the growth of Palembang City, where small administrative areas were the older established areas and generally had a higher built urban density and growth concentration intensity. In contrast, the new administrative regions have a lower urban density.

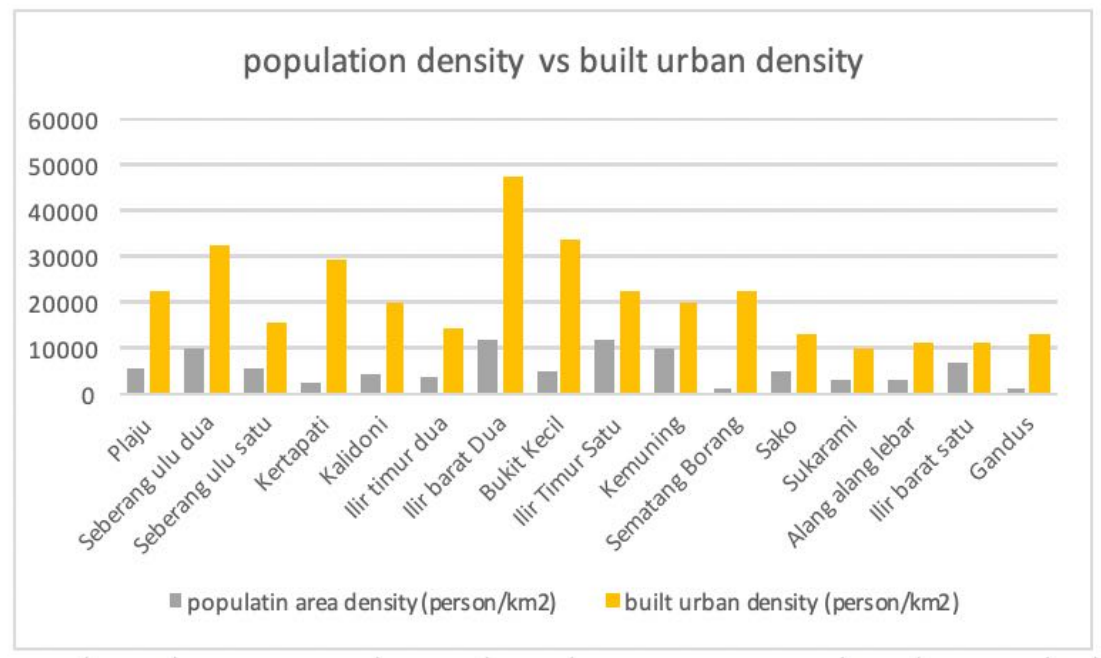

Figure 7. The population comparison between the 16 administrative areas population density vs urban built area density of Palembang

Source: Author, 2019 
Figure 6 and Figure 7 shows the value of population density from the census data by dividing the population value with the administrative area size, compared to the urban built density by dividing the population value with the built area size. The result shows that there is a difference in the actual thickness of each area.

This research findings visualize and statistically describe the population density distribution of every administrative area. The results show a comparison between the built and the unbuilt areas, in Palembang and also confirms the administrative areas that are constructed densely in oppose to the less made. At the same time, others show uneven growth by comparing built urban areas with the population census data. The most densely built administrative area is Ilir Barat Dua, with the contrast between population census and built metropolitan area of 71,267 people with $1.49 \mathrm{~km} 2$ showing the urban density of 47,673 people $/ \mathrm{km} 2$. The lowest density in the administrative area is Sukarami, with a population of 155,590 people with the built metropolitan area of $15.48 \mathrm{~km} 2$ showing the urban density of 10,048 people $/ \mathrm{km} 2$.

This result shows a different value of density in Palembang that is different from the Population density visual representation shown in Figure 2. Using the Built$\mathrm{Up}$ area land use cover and weighted using the population of each administrative area, Figure 8 shows a comparison between the population density in oppose to the built-up area density. This method of comparing the census population with administrative data is only offering information about a general density, but also show more in-depth information about the actual urban density of built urban areas.
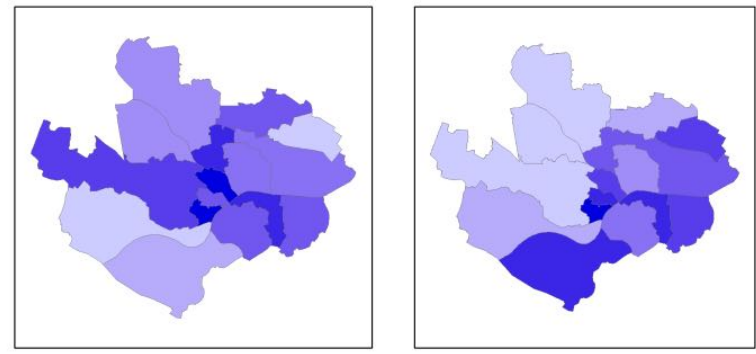

Figure 8. Comparison between population density and built area density and Population ratio in Palembang Source: Author, 2019

This research confirms the United Nation 2018 World Cities information that states the value of urban expansion with the dynamic change of the urban built-up of the city's spatial structure. The amount of change in the spatiotemporal data, with the dynamics of land use, represents the change in land use quantity in a unit time. The dynamics of land use with the extent of the urban expansion can be compared quantitatively according to the following formula:

$$
\text { LUDI }=\frac{\mathrm{Ua}-\mathrm{Ub}}{\mathrm{Ua}} \times \frac{1}{\mathrm{~T}} \times 100 \%
$$

$\mathrm{Ua}$ and $\mathrm{Ub}$ is the value of urban built areas at the time a and $\mathrm{b}$ respectively, and $\mathrm{T}$ denotes the length of time from the time a and time $\mathrm{b}$, and $\mathrm{T}$ is the unit value in $\mathrm{a}$ 
year. LUDI is the Land Use Dynamic Index and shows the annual rate of change in the area for the land-use class.

Figure 4 shows the three classifications of urban growth in Palembang of Land-use cover maps from 2001,2007, and 2016 and detected the difference in builtarea or changes from the non-built area with the built-area. In 2001, the Palembang urban built area had $66.75 \mathrm{~km} 2$, which increased to $99.02 \mathrm{~km} 2$ in 2007 and $116.25 \mathrm{~km} 2$ in 2016. The result shows the Urban built area has an annual LUDI increase of approximately $2.83 \%$ in the past 15 years $(2001-2016)$, with a rate of $3.3 \mathrm{~km} 2$ builtarea every year.

$$
\begin{aligned}
& \text { LUDI }=\frac{116.25-66.75}{116.25} \times 1 / 15 \times 100 \% \\
& =(49.5 / 116.25) \times 1 / 15 \times 100 \% \\
& =0.425 / 15 \times 100 \% \\
& =2.83 \%
\end{aligned}
$$

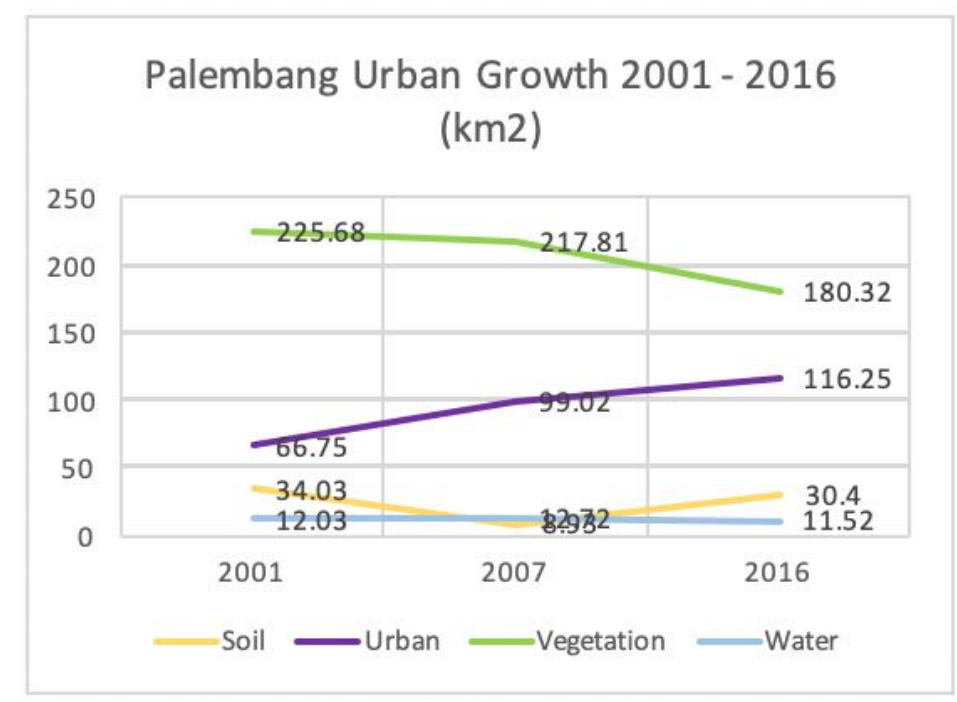

Figure 9. intensity of ULC / Urban Land cover in Palembang Source: Author, 2019

\section{Palembang Natural Street and Growth Concentration}

The urban growth in other Major Cities in South Asia and developing countries is caused by birth and migration. Among other countries in South Asia, such as Sri Lanka (1.1\%), Bangladesh (3.4\%), Nepal (3.2\%), Pakistan (3.3\%), and India (2.4\%) (Subasinghe et al., 2016). Palembang has shown significant urban growth of $\mathbf{2 . 8 3 \%}$ and can be considered a rapidly growing metropolitan area in Indonesia. The population growth and urban-built size have been driven by urban migration to metropolitan areas. It has been shown that the population growth in Palembang is also significantly high. Referring to Figure 9 from the Palembang growth from 2001 to 
2016, we could see a significant decline in vegetation land use areas after 2007, while the urban areas show a steady and consistent increase.

Urban growth and sprawl are moving simultaneously from the city's edge and becoming a dominant form (Glaeser \& Kahn, 2004). There have been changes in the Urban built area in Palembang, where the mixture of housing is more derived from the city's outer part, while commercial functions stayed at the centre. The result of Urban expansion and the government plan of creating a satellite city in Palembang of Jakabaring Sport City has impacted the city's shape. The green area has decreased rapidly in the city centre. The availability of mass transport such as the LRT / Light Rapid Transit in Palembang has created growth around the city centres. The city centre's growth should be balanced with the government's announced program to develop a healthy and balanced growth in other administrative areas in Palembang.

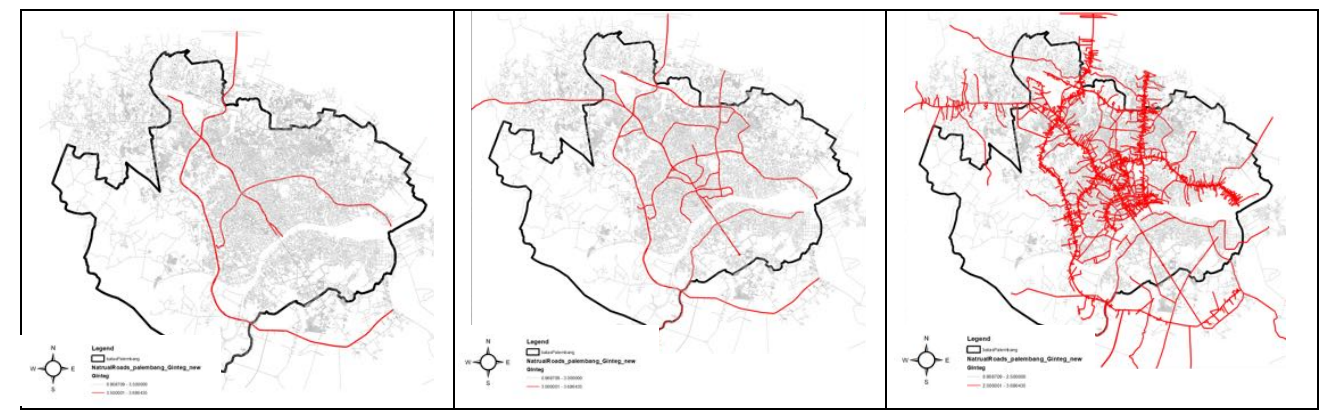

Figure 10. Global Integration of Palembang using two-tone red-grey colouring Source: Author, 2020

The condition of growth in Palembang is known as ribbon development due to the existence of the main road, i.e., Jalan Sudirman. Bhatta refers to Harvey about the concept of ribbon development as one of the major causes of urban sprawl (Bhatta, 2010). The ribbon development is the result of urban area fragmentation along the roads and the development of housing and commercial buildings and the main transportation plan that causes a direct effect on land-use planning, creating a significant urban sprawl. We could hypothesize that Palembang could result in a similar problem created by accessibility features from this urban growth density map. A needed balanced growth would be the solution for the future of Palembang. 


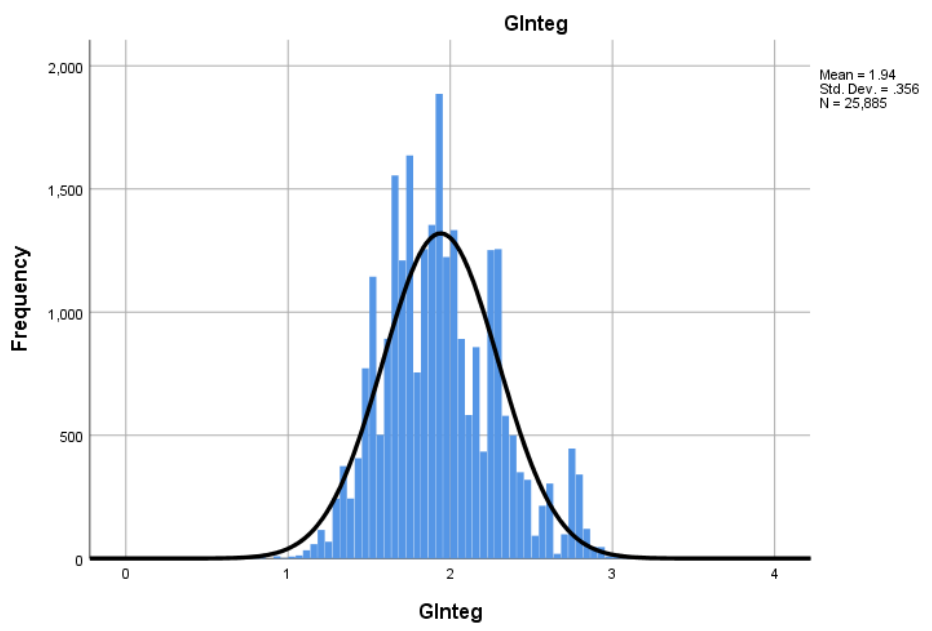

Figure 11. Global Integration histogram Palembang Source: Author, 2020

The natural street analysis from the city of Palembang in Figure 10 reveals the street network's movement pattern in Palembang. The map is clustered into three different plans to show the difference of value in Global integration on the street network. This method shows the hierarchy of the street network and could also describe as the level of the leading street network in Palembang. The first map shows a red line with a Global integration value of more than 3.5. this map shows the three dominant street networks in Palembang, with Jalan Sudirman as the primary road network connecting the northern part with the southern part of the city with two important ring roads in the town. The second map shows a red line with the Global Integration value more than 3.0, and this map shows at least 15 crucial street network in the city, while the third map shows a red line with the Global Integration value of more than 2.5. In this third map, it offers a large number of street network Palembang road network system.

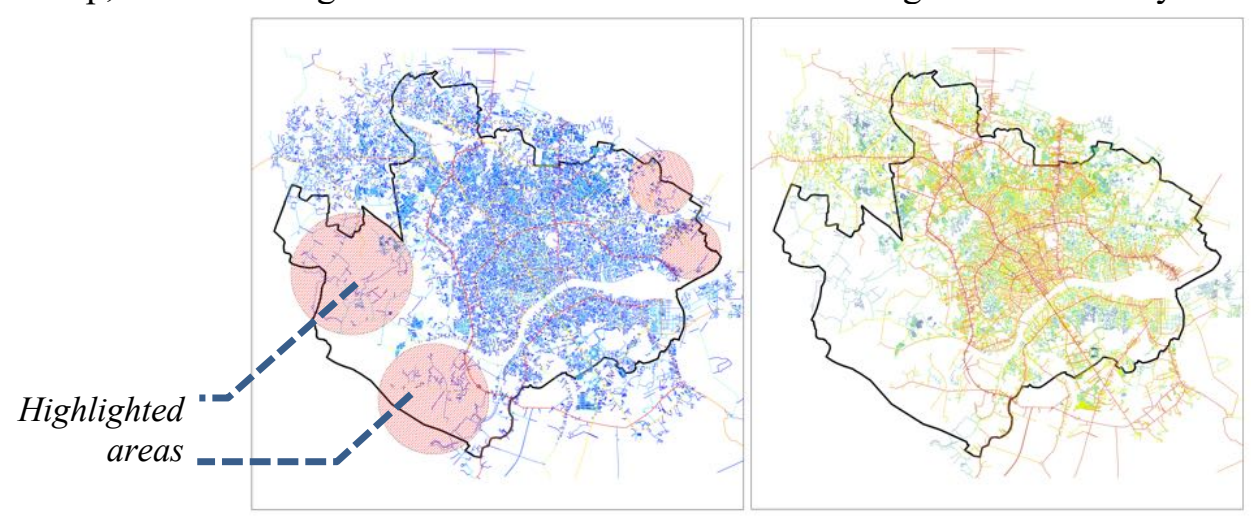

Figure 12. Global integration and Connectivity Space syntax map in Palembang Source: Author, 2020 
The global integration statistic value of the entire city of Palembang shows a maximum amount of 4.0 and a minimum value of 1.0 while the mean value of 1.94 . the linear histogram in Figure 11 indicates that the distribution of global integration in the city is $20 \%$ as the high integration value and $80 \%$ of the worldwide integration values are the mean and low integration values. The growing concentration of Palembang results shows that parts of Gandus, Kertapati, sematang boring, and kalidoni showed in Figure 12 have patches of underdeveloped regions. These highlighted areas should have more attention and planning for future development in Palembang.

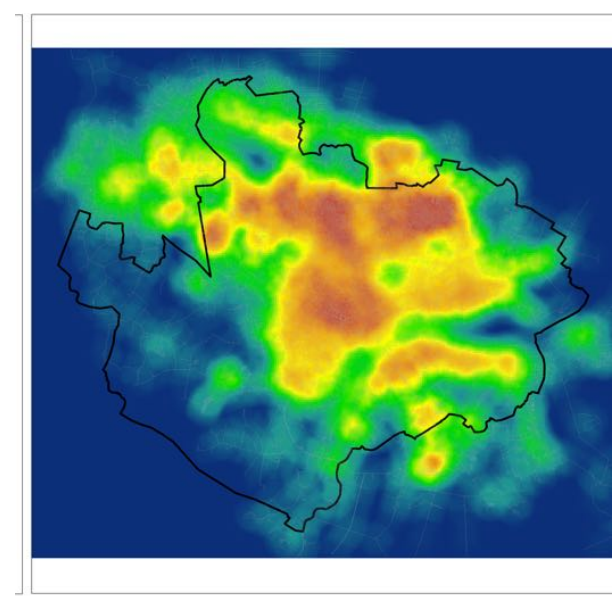

Figure 13. Linear street centerline density in Palembang Source: Author, 2020

The linear density growth concentration in Palembang's city in Figure 13 reveals that the current condition of Palembang has become a nucleated city. The gradient of colour with red and yellow colour shows a high density of the street network, and green and light blue shows a low density of the street network. The map shows areas in Palembang with high intensity of density in the central location and the northern and northeastern part of the city.

The new bridges that connect the northern part / Musi bridge IV and southern part / Musi bridge VI of Palembang have contributed significant value to the global integration value. The Ampera Bridge, in picture 1 Figure 14, has been the main connecting bridge in Palembang that connects the northern part with the southern part of the city since 1966. The Ampera bridge has been an integral part of the Global integration of the town with the global integration value of 3.05 .

The newly added bridge in picture 2 of Figure 14: Musi bridge IV that was recently operated in 2019 has connected the Pasar Kuto area with the kampong alMunawar and created an integration between the Kuto and Seberang Ulu dua with the global integration value of 2.66. The newly operational bridge in picture 3 of Figure 14: Musi bridge VI that has just been opened for public in 2020 is connecting the $K i$ Gede Ing Suro in kecamatan Ilir Barat Satu and kecamatan Seberang Ulu Satu Palembang, with the global integration value of 2.83 . 


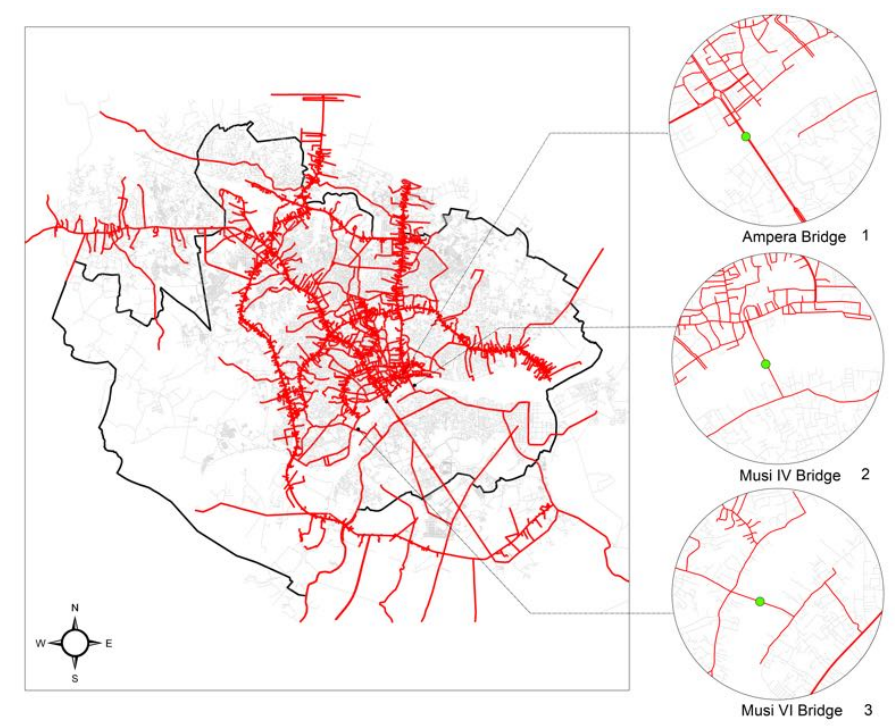

Figure 14. Global Integration of the new Bridges in Palembang Source: Author, 2020

\section{CONCLUSIONS}

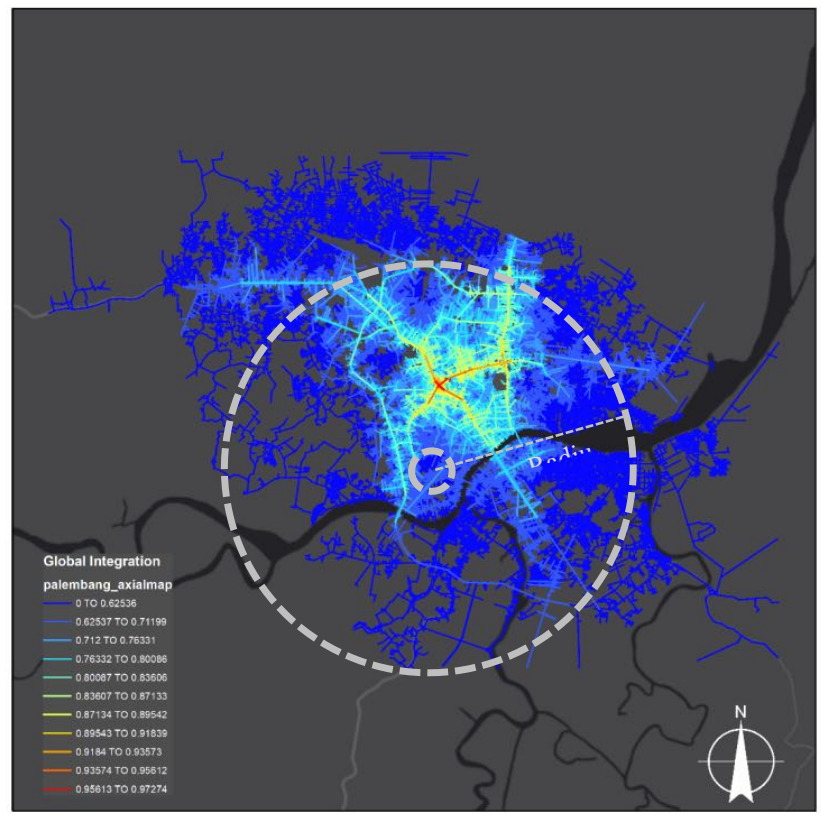

Figure 15. Axial Map Global Integration distribution of Palembang Source: Author, 2020 
Urban growth in Palembang has shown a high increase in the number of urban density areas from 2001-2007, which has created dispersions of urban patterns in the city. The Urban growth also continues with the similar way shown in the remote sensing findings in 2016. The statistical result shows the land-use area of vegetation is reducing. In contrast, the land use of the built-up area increases with the Land Use Dynamic Index size growth of $2.83 \%$ annually. This urban growth has continued evolving and creating a non-formal linear pattern linked to the city centre. This type of ribbon development growth could result in a disruptive design if Palembang's future urban planning does not address this issue. Palembang growth concentration also indicates a pattern of patches development known as multinucleated development. The disrupted multinucleated city type pattern without careful planning and unevenly distributed action could lead to urban sprawl's potential, causing environmental degradation in the future.

Although Palembang is transforming into a multinucleated city, The Generic city form in Palembang has not yet fully converted to a customarily distributed integration throughout the city. The Global Integration value from the space syntax analysis using axial map shows the high integration concentration in Palembang shifted from the river parts of Musi area of the old city and concentrating to the hinterland parts of the city. Figure 15 shows Palembang city's syntactic core is still in the linear and tree type form, where a fully developed and integrated syntactical street network should create a semilattice structure. The semilattice structure will provide continuous integration and movement of the street network and would give benefit to the city's urban growth.

The multinucleated form of the city is still evolving, and the uneven distribution of growth in the administrative area in Palembang could lead to future harm for the city's evolution. The difference in city growth concentration and urban density will create a different city intensity, where some parts of the city will be highly dense. In contrast, other details will be underdeveloped.

\section{ACKNOWLEDGMENT}

The author gratefully acknowledges Dr Mahbub Rashid for the discussion on this research topic by showing the choices in methods that are available for spatial data analysis. The writer also believes the Urban Growth and Sprawl group's incredible insight and fruitful discussions on spatial analysis methods and data resources.

\section{REFERENCES}

Adiyanto, J., Nugroho, S., \& Atyanta, A. (2018). ANALYSIS OF URBAN FORM AND INFRASTRUCTURE IN PALEMBANG. ATRIUM Jurnal Arsitektur, 4(1), 1-9.

Anderson, W. P., Kanaroglou, P. S., \& Miller, E. J. (1996). Urban form, energy and the environment: A review of issues, evidence and policy. Urban Studies, $33(1), 7-35$. 
Bauer, M. E., Loffelholz, B. C., \& Wilson, B. (2007). Estimating and mapping impervious surface area by regression analysis of Landsat imagery. In Remote sensing of impervious surfaces (pp. 31-48). CRC Press.

Bhatta, B. (2010). Analysis of urban growth and sprawl from remote sensing data. Springer Science \& Business Media.

Glaeser, E. L., \& Kahn, M. E. (2004). Sprawl and urban growth. In Handbook of regional and urban economics (Vol. 4, pp. 2481-2527). Elsevier.

Hillier, B. (2007). Space is the machine: A configurational theory of architecturespace Syntax.

Hillier, B. H., \& Hanson, J. (1984). J. 1984 The Social Logic of Space. Cambridge University.

Jabareen, Y. R. (2006). Sustainable urban forms: Their typologies, models, and concepts. Journal of Planning Education and Research, 26(1), 38-52.

Jiang, B., \& Jia, T. (2011). Agent-based simulation of human movement shaped by the underlying street structure. International Journal of Geographical Information Science, 25(1), 51-64.

Jiang, B., Zhao, S., \& Y in, J. (2008). Self-organized natural roads for predicting traffic flow: A sensitivity study. Journal of Statistical Mechanics: Theory and Experiment, 2008(07), P07008.

Joseph, M., Wang, L., \& Wang, F. (2012). Using Landsat imagery and census data for urban population density modelling in Port-au-Prince, Haiti. GIScience \& Remote Sensing, 49(2), 228-250.

Ma, D., Omer, I., Osaragi, T., Sandberg, M., \& Jiang, B. (2019). Why topology matters in predicting human activities. Environment and Planning B: Urban Analytics and City Science, 46(7), 1297-1313.

Nations, U. (2018). The World's Cities in 2018. https://www.unilibrary.org/content/publication/c93f4dc6-en

Norman, J., MacLean, H. L., \& Kennedy, C. A. (2006). Comparing high and low residential density: Life-cycle analysis of energy use and greenhouse gas emissions. Journal of Urban Planning and Development, 132(1), 10-21.

Nugroho, S. (2012). Urban Morphology at Lowland Environment in Palembang. Department-DWCU, Yogyakarta.

Omer, I., \& Jiang, B. (2015). Can cognitive inferences be made from aggregate traffic flow data? Computers, Environment and Urban Systems, 54, 219-229.

Subasinghe, S., Estoque, R., \& Murayama, Y. (2016). Spatiotemporal analysis of urban growth using GIS and remote sensing: A case study of the Colombo metropolitan area, Sri Lanka. ISPRS International Journal of Geo-Information, 5(11), 197.

Wang, F. (2006). Quantitative methods and applications in GIS. CRC Press.

Wu, C., \& Murray, A. T. (2003). Estimating impervious surface distribution by spectral mixture analysis. Remote Sensing of Environment, 84(4), 493-505.

Yang, X. (2006). Estimating landscape imperviousness index from satellite imagery. IEEE Geoscience and Remote Sensing Letters, 3(1), 6-9.

York University (Toronto, O. ) F. of E. S., \& Lang, R. (1986). Residential density and energy conservation. 
Romdhoni: UNDERSTANDING THE URBAN POPULATION DENSITY AND GROWTH CONCENTRATION IN PALEMBANG INDONESIA

This Page is Intentionally Left Blank 